\title{
Enhanced and Balanced Microalgal Wastewater Treatment (COD, N, and P) by Interval Inoculation of Activated Sludge
}

\author{
Sang-Ah Lee ${ }^{1,2}$, Nakyeong Lee ${ }^{1,2}$, Hee-Mock $\mathrm{Oh}^{1,2}$, and Chi-Yong $\mathrm{Ahn}^{1,2 *}$ \\ ${ }^{1}$ Cell Factory Research Center, Korea Research Institute of Bioscience and Biotechnology (KRIBB), Daejeon 34141, Republic of Korea \\ ${ }^{2}$ Department of Environmental Biotechnology, KRIBB School of Biotechnology, University of Science and Technology (UST), Daejeon 34113, \\ Republic of Korea
}

Received: May 16, 2019

Revised: August 9, 2019

Accepted: August 9, 2019

First published online

August 21, 2019

*Corresponding author

Phone: +82-42-860-4329;

Fax: +82-42-860-4594;

E-mail: cyahn@kribb.re.kr

pISSN 1017-7825, eISSN 1738-8872

Copyright(C) 2019 by

The Korean Society for Microbiology and Biotechnology

\begin{abstract}
Although chemical oxygen demand (COD) is an important issue for wastewater treatment, COD reduction with microalgae has been less studied compared to nitrogen or phosphorus removal. COD removal is not efficient in conventional wastewater treatment using microalgae, because the algae release organic compounds, thereby finally increasing the COD level. This study focused on enhancing COD removal and meeting the effluent standard for discharge by optimizing sludge inoculation timing, which was an important factor in forming a desirable algae/bacteria consortium for more efficient COD removal and higher biomass productivity. Activated sludge has been added to reduce COD in many studies, but its inoculation was done at the start of cultivation. However, when the sludge was added after 3 days of cultivation, at which point the COD concentration started to increase again, the algal growth and biomass productivity were higher than those of the initial sludge inoculation and control (without sludge). Algal and bacterial cell numbers measured by qPCR were also higher with sludge inoculation at 3 days later. In a semi-continuous cultivation system, a hydraulic retention time of 5 days with sludge inoculation resulted in the highest biomass productivity and N/P removal. This study achieved a further improved COD removal than the conventional microalgal wastewater treatment, by introducing bacteria in activated sludge at optimized timing.
\end{abstract}

Keywords: COD, microalgae, activated sludge, wastewater, bacteria

\section{Introduction}

Fossil fuel has been the major energy source since the industrial revolution. However, excessive consumption of fossil fuels has produced a large amount of carbon dioxide, increasing the atmospheric $\mathrm{CO}_{2}$ concentration up to 400 ppm and finally causing global warming. Some signs of fossil fuel depletion decades ago began to force humans to find alternative energy sources that are renewable and environmentally friendly. Microalgae have attracted much attention, due to their beneficial characteristics, such as an efficient $\mathrm{CO}_{2}$ capturing ability, a higher aerial productivity and no competition with crop plants for producing biofuels $[1,2]$. Microalgae have been extensively investigated to increase biomass and lipid productivity [3,4]. Most studies have focused on optimizing environmental factors $(\mathrm{pH}$, $\mathrm{CO}_{2}$, nutrient concentration and light); however, a higher production cost for algal biofuel compared to petroleum still prevents its commercialization. Therefore, its combination with wastewater treatment is now regarded as the best choice to reduce production costs [5].

Nutrients in wastewater have been removed mainly by activated sludge in a conventional biological process [6]. However, this kind of bacteria-based treatment has limited capability for nitrogen and phosphorus removal. Therefore, nitrogen and phosphorus have been removed additionally by advanced treatment processes before discharge of the wastewater. Microalgae have also been used for advanced wastewater treatment because they can effectively remove nitrogen and phosphorus. Microalgae/bacteria-based waste- 
water treatment has been investigated widely [7-11]. Bacteria in the activated sludge mainly remove organic carbon compounds in wastewater and microalgae reduce inorganic nitrogen and phosphorus compounds more effectively [7]. Bacteria are also known to be the key players in algal growth [12, 13]. The bacteria living in activated sludge are expected to help the microalgal growth. Algae and bacteria, when they were co-cultivated, could remove N, P, and COD simultaneously [10]. In municipal sewage treatment plants, the bacterial community in activated sludge remains stable, while the bacterial community in the influent to the treatment plant is constantly changing [14, 15]. For this reason, activated sludge in which bacterial populations stay stable was used in this study.

Su et al. (2012) showed that the different ratios of algae/ bacteria result in different nitrogen/phosphorus removal efficiency and biomass settleability [8]. Microalgae/bacteria ratio has greatly influenced the nutrient removal effect and biomass production on the batch process $[16,17]$. However, long treatment time [8], low biomass production for biofuels [7] and COD re-increase are still problems of algae/bacteria-based batch wastewater treatment. Although the semi-continuous or continuous processes were also tried, similar problems occurred but were not solved [7, 9, 18]. Among the problems, re-increase of COD is most intractable. Although microalgae decrease the soluble COD in wastewater during the initial growth phase, they release organic compounds during the stationary growth phase, increasing the COD again. Released organic compounds sometimes cause cell death or hinder growth as growth inhibitors [19]. COD can be divided into four categories: soluble biodegradable COD (SCOD), non-soluble slowly biodegradable COD, non-biodegradable dissolved COD, and non-biodegradable particulate COD [20]. Most of the COD in municipal wastewater is SCOD.

The main focus of this study was that COD reduction in algal cultivation could be improved by the addition of activated sludge at optimal timing, i.e. the time point of COD re-increase. Previous studies inoculated activated sludge from the start of algal cultivation using wastewater. However, this study found the best timing for optimal formation of an algae/bacteria consortium to reduce COD further. Through outdoor semi-continuous cultivation (HRT 3 and 5 days), lower concentrations of nitrogen, phosphorus, and COD in the effluent could be maintained by the addition of activated sludge, than without it.

\section{Materials and Methods}

\section{Isolation of the Microalgal Strain}

A microalga was isolated from near wastewater treatment facilities. For wastewater treatment for an extended period, microalgae that survived in winter were obtained and enriched in $50 \mathrm{ml}$ conical tubes (Corning, USA) using BG-11 media. The dominant species were selected under an optical microscope and spread onto BG-11 solid medium. Among a large number of single colonies, the dominant species was selected again from a 96-well plate (SPL Life Sciences, Korea). The isolated eukaryotic microalga was at first identified as Coelastrum sp. morphologically based on a microscope analysis using a description guide for algae [21] and further confirmed as Coelastrum microporum by analyzing its partial 18S rRNA sequence with the following primer set: $\mathrm{CH} 165 \mathrm{~F}$ (5-CGACTTCTGGAAGGGACGTA-3) and CH1780R (5-CTAGGT GGGAGGGTTTAATG-3) [22].

\section{Comparison of Different Ratios of Microalgae and Activated Sludge}

Activated sludge was obtained from the Daejeon Metropolitan City Facilities Management Corporation in Daejeon, Korea. Different ratios of algae and sludge (volumetric ratios of 2:1, 8:1, and 40:1 at biomass concentrations of $4.0 \mathrm{~g} / \mathrm{l}$ and $5.0 \mathrm{~g} / \mathrm{l}$ for microalgae and activated sludge) were compared to examine the wastewater treatment performance, particularly in terms of the COD removal. Wastewater used for algal cultivation was the primary influent to the wastewater treatment plant. The primary influent was transferred to a 1,000-ml bottle, and the working volume was $800 \mathrm{ml}$. C. microporum was inoculated at $5 \%$ and different amounts of activated sludge were inoculated into the photobioreactor. The cultivation time was 6 days, and SCOD was monitored at 24-h intervals and compared with the control (none-sludge treatment). The light intensity was $120 \mu \mathrm{mol} \mathrm{m}^{-2} \mathrm{~s}^{-1}$, and the light and dark cycle was adjusted for $12 \mathrm{~h}$ (light):12 h (dark) with an automated plug socket time switch (Metro-electricity, Korea). The cultivation temperature was $25^{\circ} \mathrm{C}$. Aeration was done at $0.2 \mathrm{vvm}$ using a globular air stone.

\section{Indoor Batch Wastewater Treatment Process}

The concentrations of the total nitrogen, phosphorus and SCOD in the primary influent to the wastewater treatment plant were around 40, 7, and $170 \mathrm{mg} / \mathrm{l}$, respectively, with daily variations. Eight hundred milliliters of primary influent were transferred into a 1,000-ml Duran bottle. The timings of the sludge inoculation were compared. The first condition was the no sludge inoculation (control). The second was a $0.8 \mathrm{ml}$ sludge inoculation at the start point of the experiment (SSI). The last group was inoculated with $0.8 \mathrm{ml}$ of activated sludge after 3 days of cultivation (3DSI). The cultivation conditions were identical with the previous ones for the comparison of different ratios. 


\section{Outdoor Semi-Continuous Wastewater Treatment Process}

Cylindrical plastic buckets $\left(530 \mathrm{~cm}^{2} \times 37 \mathrm{~cm}\right)$ with an opaque white color were used for the outdoor cultivation. The working volume was $15,000 \mathrm{ml}$. Natural sunlight was supplied with the light:dark cycle, and the maximum intensity was recorded at $2,500 \mu \mathrm{mol} \cdot \mathrm{m}^{-2} \cdot \mathrm{s}^{-1}$. Reactors were arranged in two rows in a 10-ton raceway pond, and the pond was filled with water to maintain the temperature. Bioreactors were filled with the influent that is normally supplied to the wastewater facilities. C. microporum was inoculated into each bioreactor at $5 \%$, and air was supplied at $0.2 \mathrm{vvm}$ with a globular air stone. A batch culture was conducted for 7 days. After that, the cultures were switched from a batch culture to a semi-continuous culture, and it was operated with a hydraulic retention time (HRT) of 3 days for 15 days. In the treatment group (SI, sludge inoculation), 33\% of the activated sludge was removed daily and added again at $0.33 \mathrm{ml} / 1$. The above method converges to an activated sludge concentration of $1 \mathrm{ml} / 1$ until the end of operation at a HRT of 3 days (day 15). The HRT was changed to 5 days from day 15 to 25 , and the amount of sludge inoculation was changed $(20 \%$ media removed daily and added again at $0.2 \mathrm{ml} / \mathrm{l}$ ). The constant activated sludge concentration was maintained at the end of the process.

\section{Wastewater Characterization}

COD, total dissolved nitrogen (TDN), and total dissolved phosphorus (TDP) were measured using water quality analysis kits for the COD-LR, TN-LR and TP-LR (C-Mac, Korea). The principal method of the COD measurement by the kit was based on the potassium dichromate method (closed refluxing method) [23]. TDN and TDP measurements were based on the chromotrophic acid and acid persulfate digestion methods [22]. The characteristics of wastewater is described in Table 1.

\section{Dry Cell Weight (DCW)}

A vacuum pump (Gast DOA-P504, Cole-Parmer, USA) was used to collect the algal DCW on a $25 \mathrm{~mm} \mathrm{GF/C} \mathrm{glass} \mathrm{fiber} \mathrm{filter}$ (Whatman, Germany) during filtration of the culture broth. The DCW was measured after drying at $105^{\circ} \mathrm{C}$ overnight.

\section{DNA Extraction}

Microalgae and bacteria cells were harvested with an MF membrane filter using a vacuum pump (GAST Manufacturing, USA). Total microbial DNA was extracted from the cells collected on the filter using the DNeasy Blood \& Tissue Kit (Qiagen, Germany) combined with bead-beating method for effective cell disruption. The membrane filter was cut into two equal pieces and one piece was transferred to a 2-ml microcentrifuge tube containing $400 \mu \mathrm{l}$ of a lysis buffer of the Blood \& Tissue Kit and $200 \mathrm{mg}$ of $0.1 \mathrm{~mm}$ sterile glass beads. Bead-beating was conducted by Mini-Bead Beater (Biospec Product, USA) at $2800 \mathrm{rpm}$ for $5 \mathrm{~min}$. The DNA extraction process was conducted according to the manufacturer's instruction. DNA concentration and purity were measured by a Nanodrop 1000 spectrophotometer (ND1000, Thermo Fisher Scientific, USA).

\section{Microalgae and Bacteria Gene Copy Number}

The gene copy number was analyzed with the SYBR premix for a quantitative PCR kit (RealHelix qRT-PCR Kit, Nanohelix, Korea) according to the manufacturer's instruction with $400 \mathrm{nM}$ of each primer set (23S microalgae primer set $=\mathrm{F} 5^{\prime}$ GGACAG AAAGACCCTATGAA 3', R 5' TCAGCCTGTTATCCCTAGAG 3'; bacteria $16 \mathrm{~S}$ rRNA primer set $=\mathrm{F} 5^{\prime}$ CCTACGGGAGGCAGCAG 3', R 5' ACCGCGGCTGCTGGCAC 3') [24, 25], $1 \mu \mathrm{l}$ of the DNA template and $0.1 \mu \mathrm{M}$ of ROX dye (6-carboxy-X-rhodamine, Nanohelix, Korea) as a reference dye. For both $23 \mathrm{~S}$ and 16S, the PCR cycling included a common amplification step with an initial cycle at $50^{\circ} \mathrm{C}$ for $2 \mathrm{~min}$ and at $95^{\circ} \mathrm{C}$ for $10 \mathrm{~min}$ for activation of the DNA polymerase, followed by 40 cycles of denaturation at $95^{\circ} \mathrm{C}$ for $15 \mathrm{sec}$, annealing at $60^{\circ} \mathrm{C}$ for $30 \mathrm{sec}$, and extension at $72^{\circ} \mathrm{C}$ for $30 \mathrm{sec}$ (Chromo 4 Four-Color Real-Time PCR Detection System \#359-1590G, Bio-Rad, USA) [11]. Each melting point analysis was conducted by raising the temperature from $50^{\circ} \mathrm{C}$ to $95^{\circ} \mathrm{C}$ by $1.0^{\circ} \mathrm{C} / \mathrm{s}$ while measuring the fluorescence continuously for checking the specificity of qPCR analysis.

\section{Statistical Analysis}

Student's $t$-test was conducted to compare the two groups using Microsoft Excel software. When the $p$-value was less than $0.05\left({ }^{*} p<0.05\right)$, it was judged to be significantly different. For multiple comparisons, ANOVA was done first, and HSD (Honestly significant difference test, Tukey test) followed afterwards.

\section{Results and Discussion}

\section{Prevention of the COD Re-Increase by Sludge Inoculation}

In this study, we conducted an experiment to control the

Table 1. The characteristics of municipal wastewater, activated sludge, and algal culture.

\begin{tabular}{|c|c|c|c|c|c|c|c|c|c|}
\hline & $\mathrm{pH}$ & $\begin{array}{c}\text { TS } \\
(\mathrm{mg} / \mathrm{l})\end{array}$ & $\begin{array}{c}\mathrm{VS} \\
(\mathrm{mg} / \mathrm{l})\end{array}$ & $\begin{array}{l}\text { MLSS } \\
(\mathrm{mg} / \mathrm{l})\end{array}$ & $\begin{array}{c}\text { MLVSS } \\
(\mathrm{mg} / \mathrm{l})\end{array}$ & $\begin{array}{c}\text { DCW } \\
(\mathrm{g} / 1)\end{array}$ & $\begin{array}{l}\text { SCOD } \\
(\mathrm{mg} / \mathrm{l})\end{array}$ & $\begin{array}{c}\text { TDN } \\
(\mathrm{mg} / \mathrm{l})\end{array}$ & $\begin{array}{c}\text { TDP } \\
(\mathrm{mg} / \mathrm{l})\end{array}$ \\
\hline Municipal W.W. & 7.1-7.3 & 150.0 & 109.5 & - & - & - & $95.0-166.9$ & $33.9-40.1$ & $4.0-7.1$ \\
\hline Activated sludge & $6.7-6.8$ & - & - & 5100 & 3850 & - & 67 & ND & ND \\
\hline Microalgae culture & $7.0-7.5$ & - & - & - & - & 4.0 & - & ND & ND \\
\hline
\end{tabular}

TS (total solid), VS (volatile solid), MLSS (mixed liquor suspended solid), MLVSS (mixed liquor volatile suspended solid) and DCW (dry cell weight) ND: not determined 


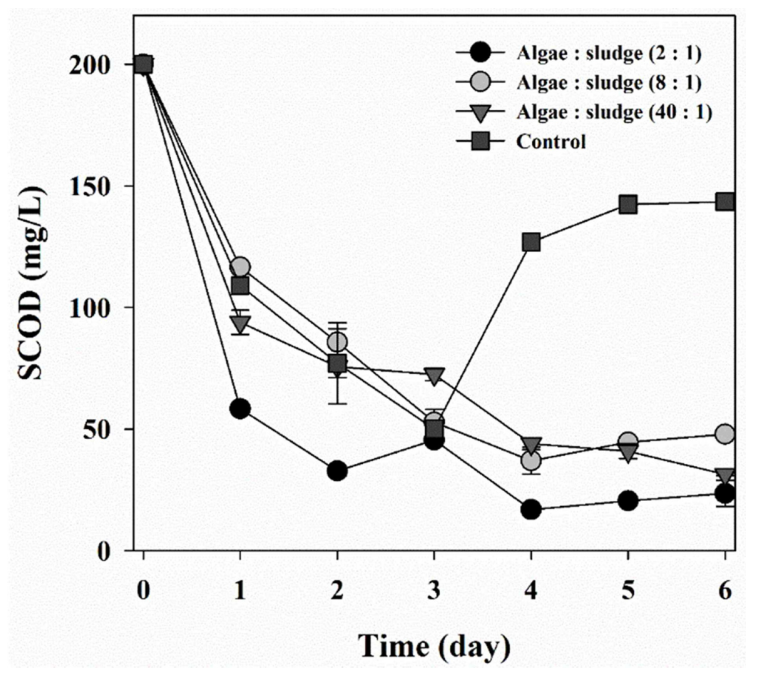

Fig. 1. Comparison of the SCOD removal at different algae:sludge ratios.

SCOD increase by adding activated sludge to the microalgae culture. When microalgae are cultured using wastewater, the SCOD decreases initially but increases again at a certain point. After finding the re-increase time point, the timing of the activated sludge inoculation could be determined. The SCOD remained decreased until six days in the sludge-added groups, but the SCOD increased again from day 3 in the control (without any sludge addition) (Fig. 1). Although the SCOD-decreasing patterns of the three algae:sludge ratios were similar, it was the fastest for the 2:1 ratio. However, the difference in the SCOD concentrations between the three algae:sludge ratios became smaller until day 6 . Therefore, an algae and sludge ratio of 40:1 was selected for the subsequent experiments because it would be more desirable to add the least amount of activated sludge for the algae cultivation. An optimal ratio of symbiotic co-cultivation also affected the nitrogen and phosphorus reduction, but COD reduction was not comparable [7]. Microalgae consume a large portion of nutrients in wastewater. A suitable algae/bacteria ratio showed a more synergetic effect on the assimilation of nitrogen/phosphorus than the pure cultivation of microalgae. However, a higher bacteria/algae ratio than optimum caused a lower assimilation of nutrients $[18,26]$. Bacteria in the activated sludge consume organic compounds and oxygen produced by the microalgae [27]. COD reduction below the effluent standard of sewage was obtained by controlling the proportion between the algae and bacteria.
In a natural environment, bacteria and microalgae basically interact through the carbon cycle. Their symbiotic ways are divided largely into mutualism and parasitism. Coevolution of algae and bacteria revolutionized life all around the earth [28]. Increasing SCOD after microalgal growth has been a problem in wastewater treatment. The SCOD increase occurs through two mechanisms. The first is the decomposition of old microalgae by bacteria, and the second is the release of organic matter after carbon dioxide fixation by microalgae [29]. Therefore, the SCOD increase may occur due to an imbalance between the bacteria and algae or a prolonged incubation period.

\section{Timing of the Sludge Inoculation in a Batch Cultivation}

After determining the added sludge amount, the timing of the sludge addition should be determined. The increase of the SCOD was observed after 3 days of culturing the microalgae (= control condition) (Fig. 1). Microalgae release organic matter after uptake of inorganic carbon through autotrophic metabolisms [30]. When microalgae stop utilizing carbon sources from the COD compounds, they begin to take up inorganic carbon sources [7]. Therefore, two time points for the sludge inoculation were compared: the starting day of the cultivation (SSI) and 3 days after the cultivation (3DSI). The SCOD concentrations decreased from 166.9 to $38.7,44.6$ and $137.8 \mathrm{mg} / \mathrm{l}$ in the 3DSI, SSI and control, respectively, after 10 days (Fig. 2A). The SCOD of the control began to increase again from day 2 and rapidly increased after 8 days up to $141 \mathrm{mg} / \mathrm{l}$. But the SCOD of SSI showed only a slight increase. However, the SCOD did not increase again in 3DSI. The biomass of the control, SSI and 3DSI reached 0.72, 0.77, and $0.95 \mathrm{~g} / \mathrm{l}$, respectively, after 10 days (Fig. 2B). Nitrogen and phosphorus decreased more slowly and continuously down to $1.2 \mathrm{mg}-\mathrm{N} / \mathrm{L}$ and $0.1 \mathrm{mg}-\mathrm{P} / \mathrm{L}$, respectively, below the strictest effluent standards of $20 \mathrm{~N}-\mathrm{mg} / 1$ and $0.2 \mathrm{P}-\mathrm{mg} / 1$ (Figs. 2C and 2D) [31].

The discharge standard for sewage is divided into four regions in Korea, and there are two different discharge standards for COD, i.e., 20 and $40 \mathrm{mg} / 1$. The COD discharge standard for the municipal wastewater used in this study is $40 \mathrm{mg} / \mathrm{l}$. Therefore, the microalgal and activated sludge wastewater treatment satisfied the effluent standard. It showed that bacteria in the primary influent alone could not effectively reduce the COD compounds produced additionally by the algae. However, the SCOD remained low by the addition of activated sludge regardless of the inoculation time. Because COD removal by the activated sludge was not strongly dependent on the algae:sludge 

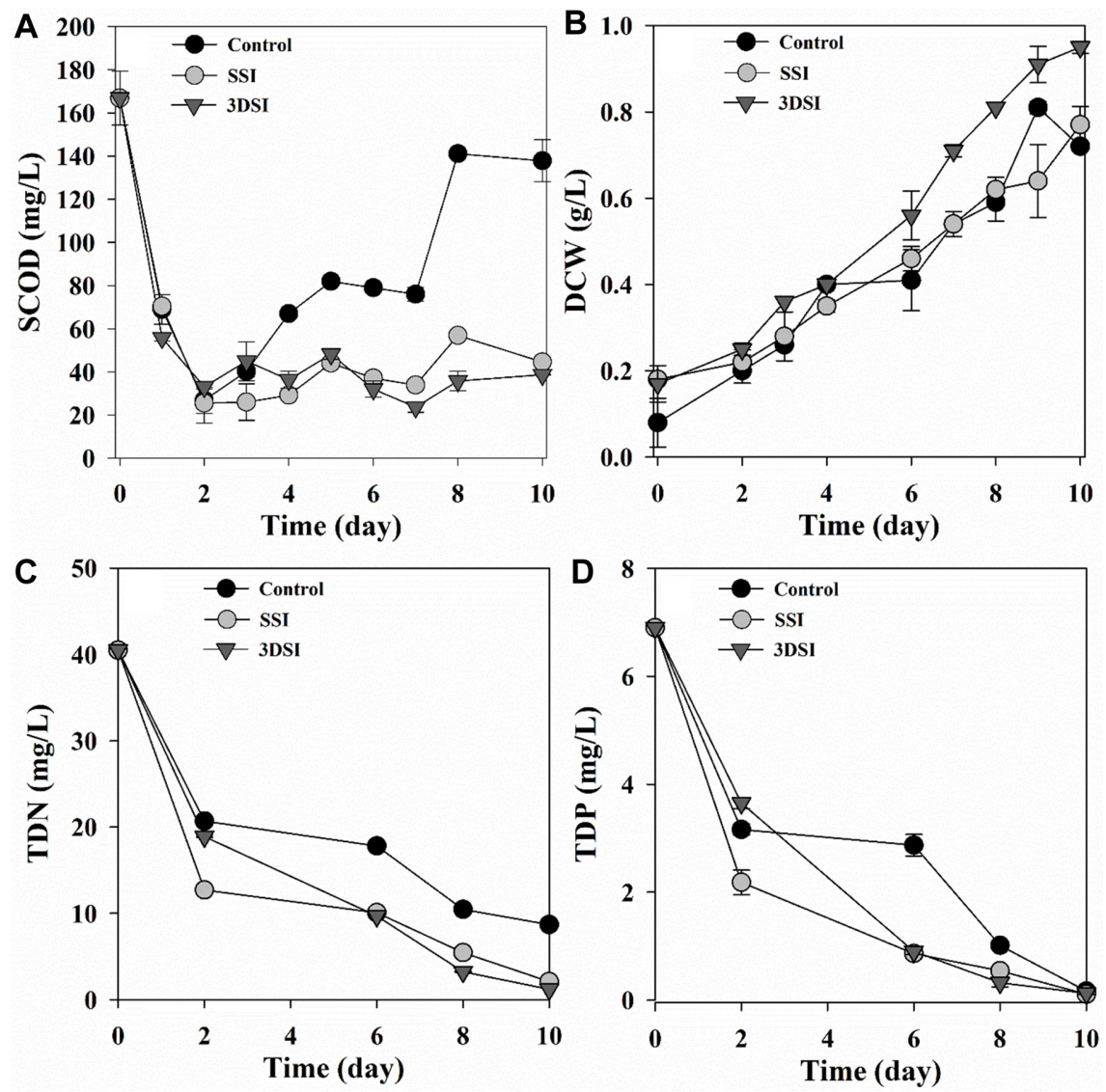

Fig. 2. Performance of the indoor wastewater treatment with different sludge inoculation times.

SCOD (A), DCW (B), TDN (C), TDP (D). SSI, starting sludge inoculation; 3DSI, 3 days after the sludge inoculation.

ratio in this study and other research [8], the sludge inoculation timing could be more important for the COD reduction than the amount of inoculum size. The 3DSI showed better performance in SCOD removal than that of the SSI without increase again. This suggests that the bacteria in the activated sludge was mainly responsible for the prevention of the COD increase again, and the timing of the sludge addition was best after 3 days of cultivation, at which time the COD started to rise again. By matching the timing of the sludge inoculation to form the appropriate consortium between the activated sludge and microalgae, the COD could be controlled, and a higher biomass productivity could be obtained (Figs. 2A and 3). Similar results from enhanced algal growth by the addition of bacteria have been reported. The biomass of Chlorella vulgaris was increased by co-cultivation with Azospirillum brasilense [32]. And Pseudomonas promoted Synechocystis growth [33]. However, when the bacteria concentration was too high, microalgal cell density was lower than pure culture of microalgae [7]. The biomass of SSI was lower than 3DSI, probably because the sludge inoculation time was too early to form an optimal consortium of algae and bacteria. Early sludge inoculation seems to bring about the competition between algae and bacteria rather than cooperation.

The 3DSI experimental group showed consistently higher growth during the entire cultivation period compared with the others (Fig. 2B). Algae generally have a longer doubling time than that of bacteria. Therefore, at the beginning stage, bacteria tend to have a higher growth rate than that of algae. The simultaneous addition of the activated sludge and microalgae at the beginning of the culture may be affected by the rapid bacterial growth. However, when the activated sludge was inoculated after some algal growth, the algae and bacteria could form a stable consortium more easily in the reactor. Biomass production reached maximum levels after 10 days of the batch cultivation. Therefore, our study showed that the sludge inoculation timing was critical to more stable SCOD reduction (Fig. 2A) and higher biomass productivity (Figs. 2B and 3). 


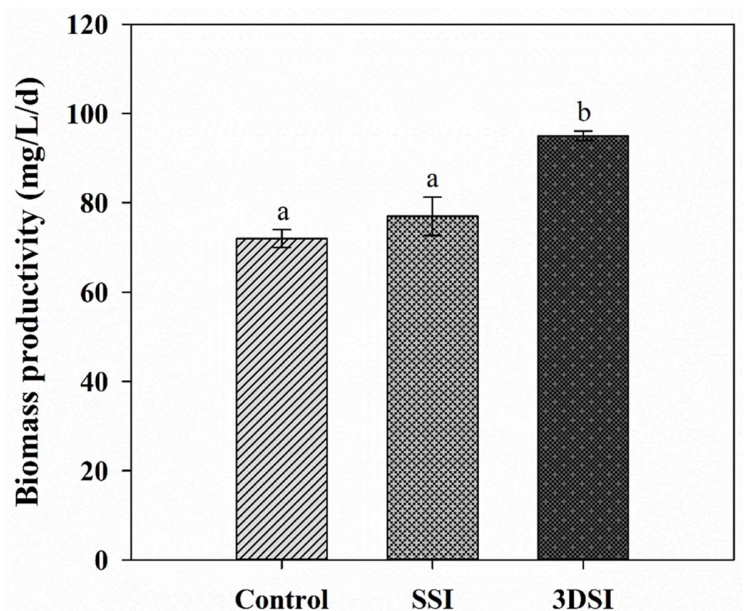

Fig. 3. Biomass productivity during indoor wastewater treatment with different sludge inoculation times.

SSI, starting sludge inoculation; 3DSI, 3 days after the sludge inoculation. Bars with different letters indicate a significant difference (Tukey test, $p<0.05$ ).

\section{Quantification of the Microalgae and Bacteria Cells by qPCR}

Gene copy numbers of the algae and bacteria were measured from the SSI, 3DSI, and control cultures (Fig. 4). Algal growth was highest in the 3DSI after 10 days of cultivation and also had the highest gene copy number compared to the other groups (Fig. 4A). The bacteria decreased in the control and SSI and only increased slightly in the 3DSI (Fig. 4B). This result suggests that the algae and bacteria consortium was adequate in the 3DSI, and this could also be supported by the result that the 3DSI had the highest microalgal biomass productivity (Fig. 3). The bacteria source of the control was different from the SSI and 3DSI. The bacteria of the SSI and 3DSI were from the activated sludge, but the bacteria in the control were from a normal influent. The bacteria consortium of the influent seems to have no effect on the efficient SCOD removal because the SCOD was increased again in the control. For the SCOD removal, the bacteria contained in the activated sludge were significantly more efficient. In terms of SCOD removal, this result means that inoculation of the activated sludge should be done at the appropriate time point to establish a proper symbiosis between the microalgae and bacteria. A study on synergistic wastewater treatment between microalgae and activated sludge bacteria reported that the microalgae growth was increased by specific bacteria, and auxotrophic cofactors such as thiamin, cobalamin and biotin were produced by bacteria [34].
A

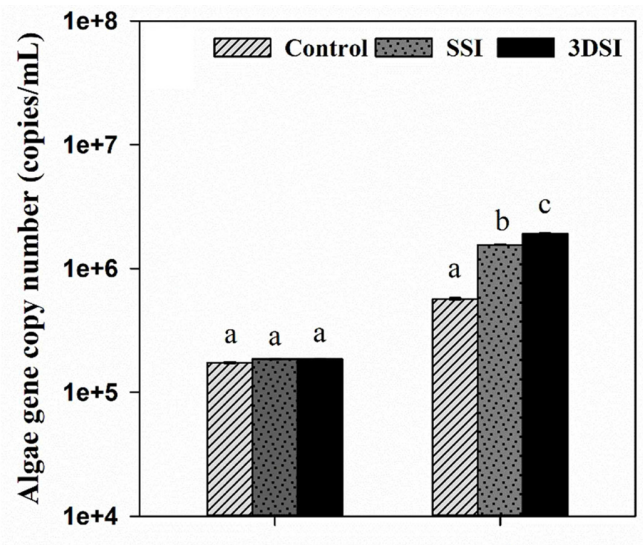

B

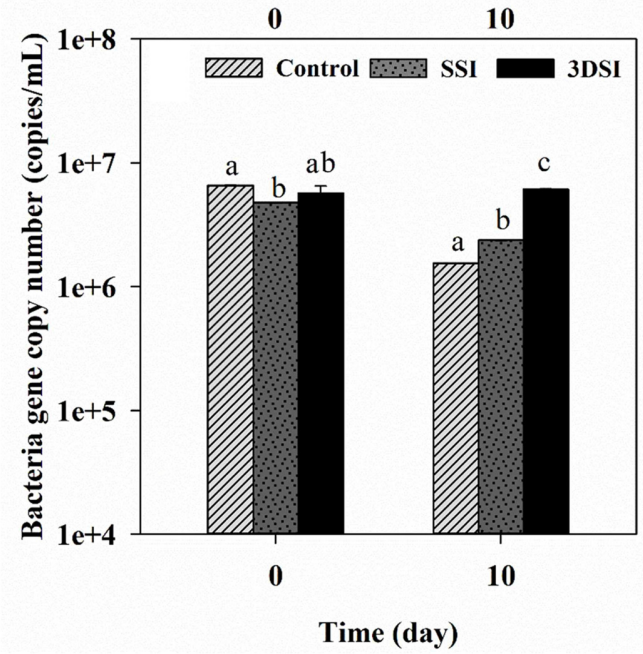

Fig. 4. Growth of the algae (A) and bacteria (B) measured by gene copy number with different sludge inoculation times.

SSI, starting sludge inoculation; 3DSI, 3 days after the sludge inoculation. Bars with different letters indicate a significant difference (Tukey test, $p<0.05$ ).

Volumetrically, the microalgae and activated sludge ratio may vary depending on the type of wastewater. In this study, the microalgae and activated sludge were applied to the influent treatment of municipal wastewater.

Effect of the HRT on the Wastewater Treatment Performance in a Semi-Continuous Cultivation

An outdoor semi-continuous cultivation was also conducted because municipal wastewater should be treated continuously. In a continuous wastewater process, the HRT is an important factor because it determines the biomass productivity and nutrient removal efficiency (Fig. 5). Short HRT and higher biomass were achieved by the two-module membrane photobioreactor for sewage treatment [35], but this membrane photobioreactor was difficult to adopt to a 

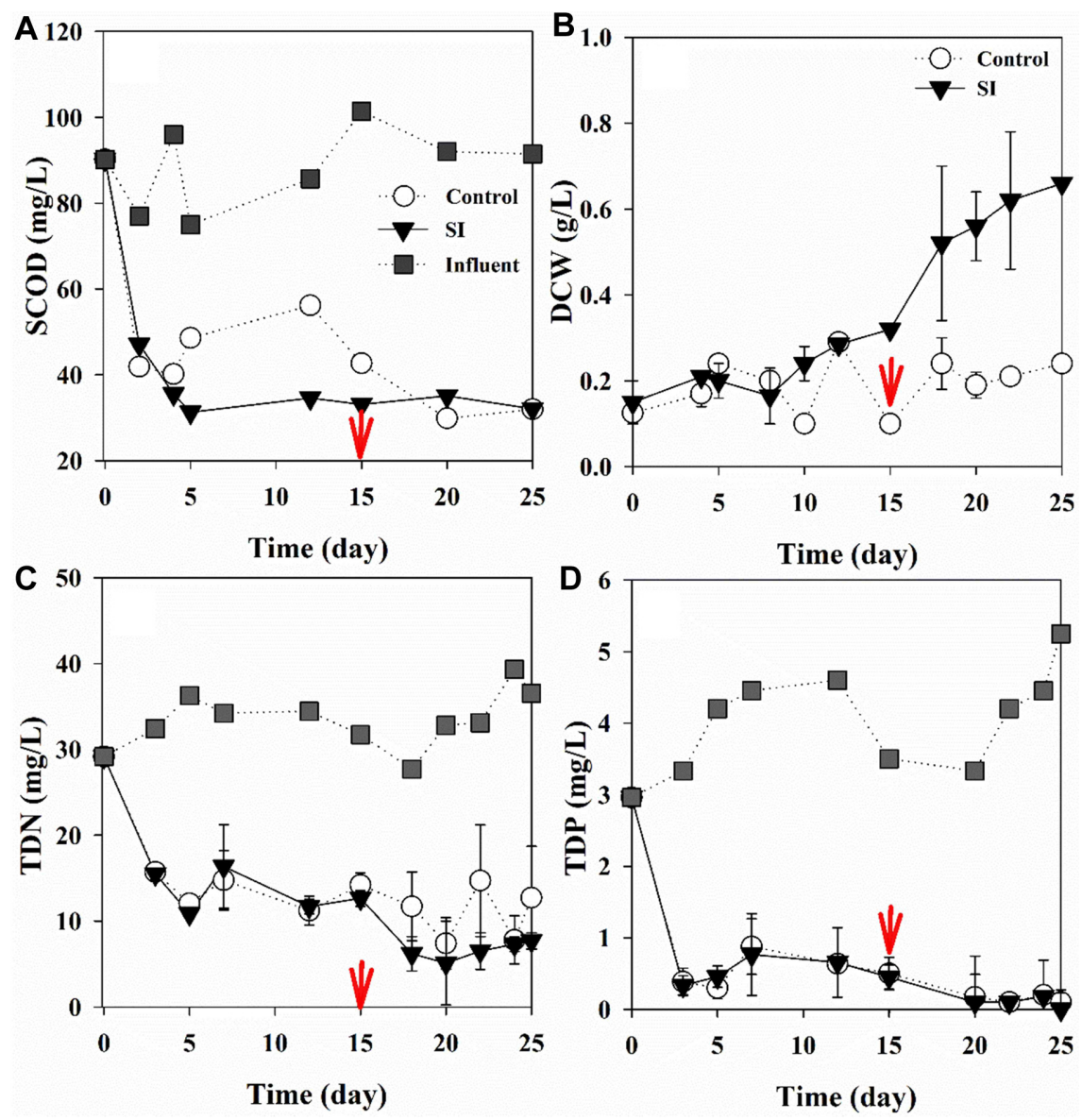

Fig. 5. Performance of the outdoor wastewater treatment at different HRTs and by inoculation of the activated sludge. $\operatorname{SCOD}(\mathbf{A}), \mathrm{DCW}(\mathbf{B}), \mathrm{TDN}(\mathbf{C})$, TDP (D). HRT was changed from 3 to 5 days on day 15 (indicated by the red arrows). SI, sludge inoculation.

scaled-up wastewater process, because it costs much more than simple photobioreactors. In addition, mixed microalgae/ sludge was used to treat pre-treated swine manure at HRT of 10 days [36]. Although the SCOD removal was variable in the control depending on the influent concentration, the SCOD removal was more efficient and stable by the sludge inoculation (Fig. 5A), through this study. The SCOD concentration in the control could be reduced below $40 \mathrm{mg} / 1$ by increasing the HRT from 3 to 5 days. The HRT of 3 days was unsuitable for wastewater treatment in the control. This phenomenon is related with the bacteria consortium stability. At a continuous treatment process for pre-treated swine wastewater, biofilm detachment in activated sludge reduced the COD removal level down to $0 \%$ [37]. However, the COD removal level began to rise after 50 days, when bacterial biofilm formed stably again. In our study, SCOD removal was unstable in the control (Fig. 5A). In the treatment group, however, COD could always be controlled regardless of HRT. Ye and Zhang [37] compared the bacterial diversity between activated sludge and influent in municipal wastewater and found that bacterial diversity was much simpler in the influent, compared with that of activated sludge. The influent was predominated by Proteobacteria, over 60\%. On the contrary, bacterial composition was more balanced in activated sludge. The imbalanced bacteria community in the influent might be more susceptible to fluctuations in the culture conditions and wastewater composition, thereby exhibiting unstable COD removal performance. In contrast, more stable COD removal with activated sludge could be attributed to the balanced bacterial composition (Fig. 5A). The SCOD was successfully reduced down to around $30 \mathrm{mg} / \mathrm{l}$ at both HRTs of 3 and 5 days when the sludge was inoculated. The COD re-increase was not observed in the semi-continuous cultivation. Because a stable symbiosis formed between the microalgae and activated sludge, COD control was possible. Increasing the HRT from 3 to 5 days improved the sewage treatment performance and biomass 
concentration at the SI (Fig. 5B). TDN and TDP were reduced below the effluent standards in both the control and SI, but TDN consumption was higher in the SI than in the control at a HRT of 5 days (Figs. 5C and 5D).

The SI group had a biomass productivity of 92.9 and $122.7 \mathrm{mg} / \mathrm{l} / \mathrm{d}$ at a HRT of 3 and 5 days, respectively (Fig. 6). However, the biomass productivity of the control was much lower at 44.0 and $42.7 \mathrm{mg} / \mathrm{l} / \mathrm{d}$ at a HRT of 3 and 5 days, respectively. Microalgal biomass productivity increased by $2.1-2.9$ times by the sludge inoculation.

A consortium of microalgae and stable bacteria diversity produced a higher microalgae biomass productivity and a lower COD concentration. However, the timing of the addition of the activated sludge should be determined precisely in the batch process to obtain the best performance. In the continuous process, a key factor was to control the HRT while maintaining the same concentration of the activated sludge as the batch process. Through this study, bacteria in the activated sludge showed two functional roles. The first role is the stable consumption of

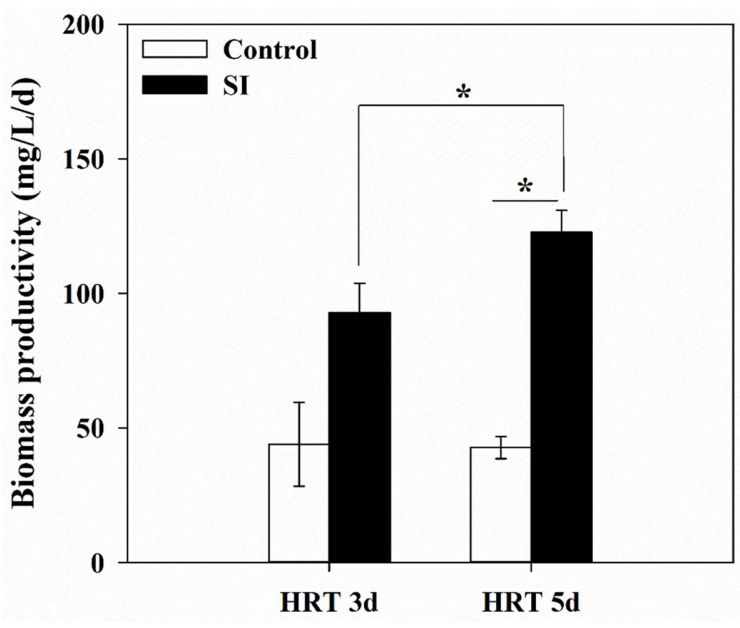

Fig. 6. Biomass productivity during the outdoor wastewater treatment at different HRTs and by inoculation of the activated sludge.

SI, sludge inoculation. Asterisks indicate a significant difference $(t-$ test, $p<0.01)$.

Table 2. Comparison of nutrient removal (TDN; TDP; SCOD), between cultivation types, sludge inoculation, and HRTs.

\begin{tabular}{|c|c|c|c|c|c|c|}
\hline \multirow{2}{*}{ Cultivation type } & & \multirow{2}{*}{ HRT (d) } & \multicolumn{3}{|c|}{ Nutrient concentration $(\mathrm{mg} / \mathrm{l})$} & \multirow{2}{*}{ Removal (\%) } \\
\hline & & & Exp. group & Influent & Effluent & \\
\hline \multirow[t]{9}{*}{ Batch $^{a}$} & \multirow[t]{3}{*}{ TDN } & - & Control & 40.1 & 8.7 & 78.3 \\
\hline & & - & SSI & 40.1 & 2.1 & 94.8 \\
\hline & & - & 3DSI & 40.1 & 1.2 & 97.0 \\
\hline & \multirow[t]{3}{*}{ TDP } & - & Control & 7.1 & 0.16 & 97.7 \\
\hline & & - & SSI & 7.1 & 0.1 & 98.6 \\
\hline & & - & 3DSI & 7.1 & 0.12 & 98.3 \\
\hline & \multirow[t]{3}{*}{ SCOD } & - & Control & 166.9 & 137.9 & 17.4 \\
\hline & & - & SSI & 166.9 & 44.6 & 73.3 \\
\hline & & - & 3DSI & 166.9 & 38.2 & 77.1 \\
\hline \multirow[t]{12}{*}{ Semi-continuous ${ }^{\mathrm{b}}$} & \multirow[t]{4}{*}{$\mathrm{TDN}$} & \multirow{2}{*}{3} & Control & 33.9 & 13.7 & 59.6 \\
\hline & & & SI & 33.9 & 13.7 & 59.6 \\
\hline & & \multirow{2}{*}{5} & Control & 33.9 & 10.9 & 67.8 \\
\hline & & & SI & 33.9 & 6.6 & 80.6 \\
\hline & \multirow[t]{4}{*}{ TDP } & \multirow{2}{*}{3} & Control & 4.0 & 0.5 & 87.5 \\
\hline & & & SI & 4.0 & 0.5 & 87.5 \\
\hline & & \multirow{2}{*}{5} & Control & 4.2 & 0.3 & 92.9 \\
\hline & & & SI & 4.2 & 0.3 & 92.9 \\
\hline & \multirow[t]{4}{*}{ SCOD } & \multirow{2}{*}{3} & Control & 85.7 & 48.4 & 43.5 \\
\hline & & & SI & 85.7 & 33.8 & 60.6 \\
\hline & & \multirow{2}{*}{5} & Control & 95.0 & 34.9 & 63.3 \\
\hline & & & SI & 95.0 & 33.4 & 64.8 \\
\hline
\end{tabular}

${ }^{a}$ Effluent values were measured after 10-day cultivation.

${ }^{b}$ Effluent values are averages of 3 samples.

SSI, starting sludge inoculation; 3DSI, 3 days after sludge inoculation; SI, sludge inoculation 
the COD compounds. The second role is to form an adequately stable consortium with the microalgae, thereby promoting microalgal growth.

Domestic wastewater treatment with algae cultivation was achieved not only in terms of the N/P removal but also the SCOD removal by an adequate mixture of algae and activated sludge. Such a mixed cultivation of algae and bacteria could make the whole treatment performance better than the final standard for the effluent discharge. The batch and continuous wastewater treatment results are summarized in Table 2. The maximum SCOD removals were $77.1 \%$ and $64.8 \%$ in the batch and semi-continuous cultivation with the sludge inoculation. One drawback of the microalgae cultivation in the wastewater treatment (i.e., inefficient COD removal) could be solved by the addition of a small amount of activated sludge. Additionally, algal biomass productivity was also improved.

\section{Acknowledgments}

This work was supported by the Korea Research Institute of Bioscience and Biotechnology (KRIBB) Research Initiative Program and the Advanced Biomass R\&D Center (ABC), a Global Frontier Program funded by the Korean Ministry of Science and the ICT (2010-0029723).

\section{Conflict of Interest}

The authors have no financial conflicts of interest to declare.

\section{References}

1. Razzak SA, Hossain MM, Lucky RA, Bassi AS, de Las H 2006. Integrated $\mathrm{CO}_{2}$ capture, wastewater treatment and biofuel production by microalgae culturing - a review. Renew. Sust. Energ. Rev. 27: 622-653.

2. Chisti Y. 2007. Biodiesel from microalgae. Biotechnol. Adv. 25: 294-306.

3. Gao F, Yang HL, Li C, Peng YY, Lu MM, Jon WH, et al. 2019. Effect of organic carbon to nitrogen ratio in wastewater on growth, nutrient uptake and lipid accumulation of a mixotrophic microalgae Chlorella sp. Bioresour. Technol. 282: 118-124.

4. Menegazzo ML, Fonseca GG. 2019. Biomass recovery and lipid extraction processes for microalgae biofuels production: a review. Renew. Sust. Energ. Rev. 107: 87-107.

5. Park JBK, Craggs RJ, Shilton AN. 2011. Wastewater treatment high rate algal ponds for biofuel production. Bioresour. Technol. 102: 35-42.
6. Nurdogan Y, Oswald WJ. 1995. Enhanced nutrient removal in high rate ponds. Water Sci. Technol. 31: 33-43.

7. Mujtaba G and Lee K. 2017. Treatment of real wastewater using co-culture of immobilized Chlorella vulgaris and suspended activated sludge. Water Res. 120: 174-184.

8. Su Y, Mennerich A, Urban B. 2012. Synergistic cooperation between wastewater-born algae and activated sludge for wastewater treatment: Influence of algae and sludge inoculation ratios. Bioresour. Technol. 105: 67-73.

9. Lee JH, Lee JJ, Shukla SK, Park JH, Lee TK. 2016. Effect of algal inoculation on COD and nitrogen removal, and indigenous bacterial dynamics in municipal wastewater. $J$. Microbiol. Biotechnol. 26: 900-908.

10. Roudsari FP, Mehrnia MR, Asadi A, Moayedi Z, Ranjbar R. 2013. Effect of microalgae/activated sludge ratio on cooperative treatment of anaerobic effluent of municipal wastewater. Appl. Biochem. Biotechnol. 172: 131-140.

11. Lee CS, Lee SA, Ko SR, Oh HM, Ahn CY. 2015. Effects of photoperiod on nutrient removal, biomass production, and algal-bacterial population dynamics in lab-scale photobioreactors treating municipal wastewater. Water Res. 68: 680-691.

12. Amin SA, Hmelo LR, Van HM, Durham BP, Carlson LT, Heal KR. 2015. Interaction and signaling between a cosmopolitan phytoplankton and associated bacteria. Nature 522: 98-101.

13. Kim BH, Ramanan R, Cho DH, Oh HM, Kim HS. 2014. Role of Rhizobium, a plant growth promoting bacterium, in enhancing algal biomass through mutualistic interaction. Biomass Bioenergy 69: 95-105.

14. Shchegolkova NM, Krasnov GS, Belova AA, Dmitriev AA, Kharitonov SL, Klimina KM, et al. 2016. Microbial community structure of activated sludge in treatment plants with different wastewater compositions. Front. Microbiol. 7: 90.

15. Chen Y, Ye L, Zhao F, Xiao L, Cheng S, Zhang XX. 2017. Bacterial community shift during the startup of a full-scale oxidation ditch treating sewage. J. Microbiol. Biotechnol. 27: 141-148.

16. Garcia J, Mujeriego R, Hernandez-Marine M. 2000. High rate algal pond operation strategies for urban wastewater nitrogen removal. J. Appl. Phycol. 12: 331-339.

17. Guieysse B, Borde X, Munoz R, Hatti-Kaul R, NugierChauvin C. 2002. Influence of the initial composition of algal bacterial microcosms on the degradation of salicylate in fed batch culture. Biotechnol. Lett. 24: 531-538.

18. Mujtaba G, Rizwan M, Lee K. 2015. Simultaneous removal of inorganic nutrients and organic carbon by symbiotic coculture of Chlorella vulgaris and Pseudomonas putida. Biotechnol. Bioprocess Eng. 20: 1114-1122.

19. Grobbelaar JU. 2009. Factors governing algal growth in photobioreactors: the "open" versus "closed" debate. J. Appl. Phycol. 21: 489-492. 
20. Joanna SS, Justyna T. 2018. Analysis of bakery sewage treatment process options based on COD fraction changes. J. Ecol. Eng. 19: 226-235.

21. Belcher H, Swale E. 1976. A Beginner's Guide to Freshwater Algae, pp. 14-15. Institute of Terrestrial Ecology, Natural Environmental Research Council, London.

22. Cho DH, Ramanan R, Kim BH, Lee J, Kim S, Yoo C, et al. 2013. Novel approach for the development of axenic microalgal cultures from environmental samples. J. Phycol. 49: 802-810.

23. APHA. 2012. Standard Methods for the Examination of Water and Wastewater. pp. 1396. $22^{\text {nd }}$ Ed. American Public Health Association (APHA), Washington, DC.

24. Sherwood AR and Presting GG. 2007. Universal primers amplify a $23 \mathrm{~S}$ rDNA plastid marker in eukaryotic algae and cyanobacteria. J. Phycol. 43: 605-608.

25. Nadkarni MA, Martin FE, Jacques NA, Hunter. 2002. Determination of bacterial load by real-time PCR using a broad-range (universal) probe and primers set. Microbiology 148: 257-266.

26. Liang Z, Liu Y, Ge F, Xu Y, Tao N, Peng F, et al. 2013. Efficiency assessment and $\mathrm{pH}$ effect in removing nitrogen and phosphorus by algae-bacteria combined system of Chlorella vulgaris and Bacillus licheniformis. Chemosphere 92: 1383-1389.

27. Han J, Zhang L, Wang S, Yang G, Zhao L, Pan K. 2016. Coculturing bacteria and microalgae in organic carbon containing media. J. Biol. Res. 23: 1-9.

28. Ramanan R, Kim BH, Cho DH, Oh H-M, Kim H-S. 2016. Algae-bacteria interactions: evolution ecology and emerging applications. Biotechnol. Adv. 34: 14-29.

29. Ramaraj R, Tsai DD-W, Chen PH. 2015 Carbon dioxide fixation of freshwater microalgae growth on natural water medium. Ecol. Eng. 75: 86-92.
30. Zhao X, Zhou Y, Huang S, Qiu D, Schideman L, Chai X, et al. 2014. Characterization of microalgae-bacteria consortium cultured in landfill leachate for carbon fixation and lipid production. Bioresour. Technol. 156: 322-328.

31. Jeong DH, Choi IC, Cho YS, Chung HM, Kwon OS, Yu SJ, et al. 2014. A study on the management system improvement of effluent water qualities for public sewage treatment facilities in Korea. J. Environ. Impact Assess. 23: 296-314.

32. de-Bashan LE, Moreno M, Hernandez JP, Bashan Y. 2002. Removal of ammonium and phosphorus ions from synthetic wastewater by the microalgae Chlorella vulgaris co-immobilized in alginate beads with the microalgae growth promoting bacterium Azospirillum brasilense. Water Res. 36: 2941-2948.

33. Abed RMM. 2010. Interaction between cyanobacteria and aerobic heterotrophic bacteria in the degradation of hydrocarbons. Int. Biodeterior. Biodegrad. 64: 58-64.

34. Higgins BT, Gennity I, Fitzgerald PS, Ceballos SJ, Fiehn O, Vandergheynst S. 2018. Algal-bacterial synergy in treatment of winery wastewater. NPJ. Clean Water. 1: article number 6.

35. Honda R, Teraoka Y, Noguchi M, Yang S. 2017. Optimization of hydraulic retention time and biomass concentration in microalgae biomass production from treated sewage with a membrane photobioreactor. J. Water Environ. Technol. 15: 1-11.

36. González C, Marciniak J, Villaverde S, León C, García P A, Muñoz R. 2008. Efficient nutrient removal from swine manure in a tubular biofilm photo-bioreactor using algae/ bacteria consortia. Water Sci. Technol. 58: 95-102.

37. Ye L and Zhang T. 2013. Bacterial communities in different sections of a municipal wastewater treatment plant revealed by $16 \mathrm{~S}$ rDNA 454 pyrosequencing. Appl. Microbiol. Biotechnol. 97: 2681-2690. 